UDC 378:147:51:004

Taras Kobylnyk

$\mathrm{PhD}$ of Pedagogical Sciences, Associate Professor at the Informatics and Information System Department Drohobych Ivan Franko State Pedagogical University, Drohobych, Ukraine

ORCID ID 0000-0002-2703-7570

kobylnyktaras@gmail.com

\title{
Uliana Kohut
}

$\mathrm{PhD}$ of Pedagogical Sciences, Associate Professor at the Informatics and Information System Department Drohobych Ivan Franko State Pedagogical University, Drohobych, Ukraine

ORCID ID 0000-0002-2861-2274

ulyana300l@gmail.com

\author{
Nataliia Vynnytska \\ $\mathrm{PhD}$ of Pedagogical Sciences, \\ Associate Professor at the Mathematics, Informatics and Teaching Methods in Primary School \\ Drohobych Ivan Franko State Pedagogical University, Drohobych, Ukraine \\ ORCID ID 0000-0003-2784-3465 \\ Natalya.86@ukr.net
}

\section{CAS MAXIMA AS A TOOL FOR FORMING RESEARCH SKILLS IN THE PROCESS OF PRE-SERVICE INFORMATICS TEACHERS TRAINING}

\begin{abstract}
The article looks at the means of forming the research skills of students of pedagogical universities. Considerable attention is paid to the formation of students' creative thinking in the process of solving problems with parameters. A large number of applied problems, economic, physical, chemical, biological, technical, medical, etc., involve solving problems with parameters (within the framework of the constructed mathematical model). Tasks with parameters require more general research than ordinary equations, inequalities and their systems. In the article, solving problems with parameters is accompanied by graphical visualization followed by the use of the analytical method. CAS Maxima is used for graphical visualization (animation). The choice of tasks with parameters is due to the fact that mathematical, logical thinking and the ability to analyze, compare, synthesize, develop research skills evolve in the course of their solution. All this should lead to the search and introduction of new forms of pedagogy and technologies in education. The main component of the methodology here is computer-oriented, namely the use of a computer mathematics system. Using systems of computer mathematics, the student can improve the programming technique and ability to focus on the analysis of methods, immerse in the features of such concepts as the conditionality of the problem, the stability of the method, evaluation of the results of calculations. In this paper, we used the CAS Maxima animation tools with the wxMaxima graphical shell to investigate the problems with the parameters. The choice of the Maxima system is due to the following reasons: it is a freely distributed system, distributed under the GNU/GPL license; there are implementations under various operating systems, including Windows, Linux, MacOS; it offers intuitive interface and is easy and reliable in operation. The results of the study show that training of modern specialists, the development of their professional potential can only be effective provided that students are involved in research activities throughout their course of study.
\end{abstract}

Keywords: Maxima; computer algebra system; tasks with parameters; research skills.

\section{INTRODUCTION}

Formulation of the problem. The changes that are taking place in modern society, in education, in particular, lead to the development and application of new pedagogical technologies aimed at individual work with students. In training, it is necessary to pay special attention to the individual development of students' personalities, the search and development 
of their creative abilities, the formation of skills enabling them to solve problems independently. Students need to be able to think independently, apply knowledge, be able to plan activities, ask questions and find answers to them, collaborate effectively in groups. All this should lead to the search and introduction of new pedagogical forms and technologies in education. One of these forms is students' research.

Various aspects of the formation of students' research skills in a pedagogical university, intensification of research activity, as well as the question of improvement of teaching methods based on educational-research approach have been considered by many scholars in the field of education. According to our analysis, the ways of addressing these issues have always corresponded to a certain state of development of the educational system, the level of psychological-pedagogical and organizational-methodological research.

First of all, it is important to develop the ability to define a goal, to see a task, to choose the ways and means to accomplish this task and to apply the acquired knowledge in practice. Educational research activity necessarily requires that an individual should have creative potential. At all stages of mastering research skills, students learn to use different mental operations, to form a plan for further activities based on their conclusions.

One of the means of forming research skills is tasks with parameters. These tasks play a role in forming students' logical thinking and mathematical culture. Students who have mastered methods of solving tasks with parameters successfully cope with other tasks. A large number of applied problems, in particular economic, physical, chemical, biological, technical, medical, etc., are reduced to the need to solve tasks with parameters (within the built mathematical model) [1].

We suggest studying tasks with parameters within the discipline "Mathematical basics of informatics" in informatics teachers' curriculum (the same opinion is shared by the authors of the article [2]).

Analysis of recent research and publications. In [3] the authors present an analysis of students' work with algebraic expressions and problems involving parameters. They found that students had great difficulties in working with parameters and suggested using geometric contexts to help learners comprehend the meaning of parameters.

In [4] the authors substantiated the principles of formation and development of a cloudoriented educational and scientific environment of a higher educational institution.

In [5] the authors analyzed the issue of personalized learning as a global trend of modern ICT-based educational systems.

In [6] the authors show that the appropriate use of computer graphing software has the potential to avoid errors and overcome misconceptions associated with the notion of equivalence in solving inequalities.

In [7] the authors note that the computer algebra systems (CAS) have potential to facilitate an active approach to learning, to allow students to become involved in discovery and to consolidate their own knowledge, thus developing conceptual and geometrical understanding and a deeper approach to learning.

The experience of teaching mathematics to first-year engineering students with the help of the open source CAS Sage is featured in [8].

In the dissertation [9, p. 286-295], the author proposes to research the task with parameters at the stage of solving educational problems using computer-based teaching tools. Gran1 was chosen as a tool in the dissertation [10].

N.O. Buhaiets' dissertation states that the development of students' intellectual abilities takes place, their educational and research skills and mathematical culture are formed and developed in the process of solving tasks with parameters [11]. The author examines examples of using the Gran1 pedagogical software to solve parameter-dependent integrals and to investigate the dynamics of growth in predator and prey populations by using CAS Mathcad. 
In [12] the authors chose CAS MAXIMA as a learning tool.

Article [13] discusses some methodological features of teaching computer modeling of processes and phenomena using animation. CAS Maxima tools for animation modeling are described. In [14] the authors propose to solve research tasks, including equations and inequalities with parameters, using the GeoGebra dynamic mathematics system [15] as a means of intensifying research activities in the process of teaching mathematical disciplines.

In [16], the authors claim that some students experience difficulties in solving tasks with parameters. In [17] the authors provide a method for solving quadratic equations with parameters. The basic idea is to use graphical methods in combination with analytical methods.

The purpose of the article is to look into the problem of forming research skills of preservice IT teachers and to consider and evaluate the use of the Maxima system as a learning tool in the process of solving tasks with parameters.

\section{RESEARCH RESULTS}

In the pedagogical dictionary [18], the research method is interpreted as a method of involving students in independent and direct observations, based on which they establish connections between objects and phenomena of reality, draw conclusions, and learn patterns. Introducing an element of research into educational activities contributes to the formation of activity, initiative and curiosity, develops students' thinking, and encourages the need for independent search [18, p.102].

According to I.Ya. Lerner, the research method is the basic method of teaching, developing skills and creative activity, the essence of which is as follows. In the process of its application, the traits of creative activity are formed, students acquire creative knowledge, learn to apply known knowledge to solve problem tasks and to acquire new knowledge. This ensures mastery of scientific knowledge. The purpose of the research method is to organize students' search and creative activity to solve problem tasks [19, p. 103].

According to V.M. Lytovchenko, research skills can be divided into the following groups [20]:

- operational research skills, that is, being able to use a variety of mental techniques and operations used in research activities, namely comparison, analysis and synthesis, abstraction and generalization, hypothesis, comparison;

- organizational research skills, that is, being able to apply techniques to the organization of research activities, to plan research work, to carry out self-analysis, to regulate actions in the process of research activity;

- practical research skills, that is, being able to process literary sources, carry out experimental studies, process observational data, implement results in practical activities;

- communicative research skills, that is, being able to apply methods of cooperation in the process of research activities for mutual assistance and mutual control.

As M.I. Zhaldak notes, the teacher, like any specialist, must independently acquire new knowledge, find the necessary information, and use modern information resources. For this purpose, he/she must know where, how and what information to look for, how to analyze and summarize it, using it in professional activity, for which he/she needs an adequate supply of knowledge, and not small [22, p. 8].

As Ye.I. Mashbyts points out, the research approach in teaching is the key to improving mathematical education, the development of creative, intellectual abilities, students' educational and research skills [21]. According to M.I. Zhaldak, you cannot be a good programmer without the ability to solve math problems, because the teaching of computer science forms the ability to analyze, think logically, carry out heuristic search, facilitates creativity, ability to prove or refute various hypotheses, make argumentative conclusions 
about the phenomena being investigated and the cause and effect relationships between them. Algorithmization and programming are the same mathematics: analysis of the conditions of the task, construction of a mathematical (or informational) model of the task, decomposition of a task into subtasks to the simplest ones that can be solved in an elementary way [22, p. 8].

Forming an algorithmic style of thinking is an important component of teaching preservice informatics teachers. One of the tasks of higher education institutions is the development of students' creativity, initiative and independence. Informatics, like no other science, contributes to the development of an algorithmic style of thinking, which is an important component of the formation of research skills.

We have chosen the tasks with parameters because in the process of solving them mathematical, logical thinking is developing, as well as the ability to analyze, compare, summarize; research skills are forming. This is due to the fact that each task with parameters is a whole class of routine tasks, each of which must be solved. In addition, solving problems with parameters helps to formulate students' ability to develop skills concisely and transparently, to sort through all possible variants of arrangement of graphs depending on the value of the parameter, which is the basis for the development of research skills.

Resolving various tasks with parameters is important in the process of fundamental training of informatics teachers. At the same time, the acquired competences are integrative, which facilitates cross-curricular linkages and the formation of research activities.

A task (equation, inequality, system of equations, system of inequalities, etc.) with a parameter is a task that, in addition to variables and numerical coefficients, includes alphabetic coefficients that are quantities not specified but they are considered known on some numerical set.

There is no single algorithm for solving tasks with parameters. In general, analytic and graphical methods of solving are used. It is convenient to use such graphical methods as parallel transfer, rotation and homothetic transformation.

Depending on the role assigned to the parameter, there are two main techniques: building a graphic image on the coordinate axis $x O y$ or $x O a$.

The use of information and communication technologies (ICT), in particular CAS, in the training of informatics teachers at a pedagogical university gives the possibility to extend didactic applications of research approach, not to reduce it only to methods of observation, experiment, laboratory method, but to consider tasks of research nature.

Tasks with parameters are research tasks where it is advisable to use information and communication technologies, such as CAS, to do graphical constructions or various calculations. Ye.F. Vinnychenko outlines the following criteria for CAS selection: methodological expediency; intuitive interface; licensed purity [23]. CAS Maxima fully meets these criteria.

In this article, solving tasks with parameters is accompanied by graphical visualization, followed by the analytical method. CAS Maxima, including the wxanimate_draw function, was used for graphic rendering (animation). For explicitly specified dependencies the explicit statement is used, for implicitly specified implicit ones. After calculations are completed and the drawing is highlighted, three elements for animation control become available in the upper panel (Fig. 1). More detailed information about graphical constructions in the Maxima system can be found in [24, p. 157-176].

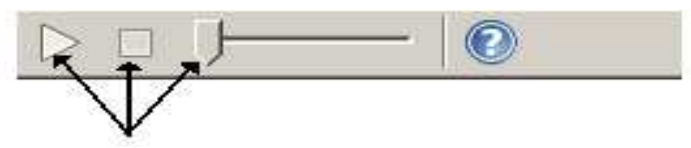

Fig. 1 


\section{Consider some examples.}

Example 1. At what values of the parameter $a$ do roots of the equation $\left|\mathrm{x}-\mathrm{a}^{2}\right|=-\mathrm{a}^{2}+$ $2 \mathrm{a}+3\left|x-a^{2}\right|=-a^{2}+2 a+3$ have the same roots in sign [25, p. 93]?

Solution. Let $f_{1}=\left|x-a^{2}\right|, f_{2}=-a^{2}+2 a+3$. Graphically $f_{1}$ defines a family of "right angles" whose vertices are to the right of the origin on the axis $O X$. Note that we should exclude $a=0$ from consideration since the equations will have different roots. Graphically $f_{2}$ defines a family of right lines, parallel to axis $O X$. Let us turn to graphical visualization (Fig. 2). As can be seen, the roots of the equation are the same in sign provided that:

- the parameter value a is within from -1 (Fig. 2, case 2 ) to $\approx-0,8$ (Fig. 2, case 3 );

- the parameter value a is within from $\approx 1,8$ (Fig. 2, case 4) to 3 (Fig. 2, case 5).
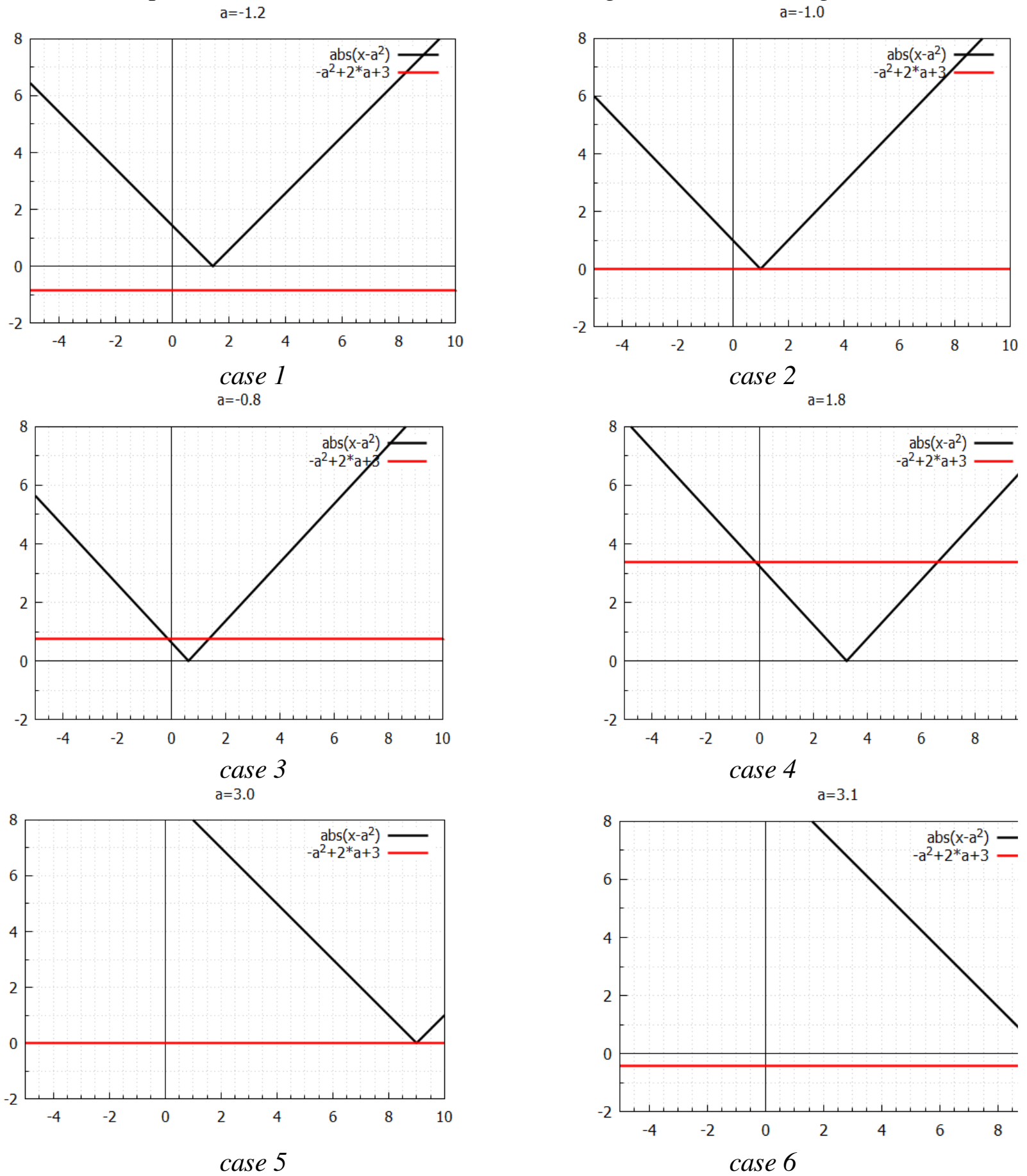

Fig. 2 
To clarify parameter values $a 3$ let's turn to the analytic method of solution. According to the task, the graphs $f_{1}$ and $f_{2}$ should intersect at the points whose abscesses have the same sign values. This is possible under the following conditions:

$$
\left\{\begin{array}{l}
-a^{2}+2 a+3<a^{2} \\
-a^{2}+2 a+3>0
\end{array}\right.
$$

Having solved the following system of inequalities, we get the answer:

$$
a \in\left(-1 ;-\frac{\sqrt{7}-1}{2}\right) \cup\left(\frac{\sqrt{7}+1}{2} ; 3\right) \text {. }
$$

It should be noted that, compared to CAS Mathematica and Maple, Maxima has limited use in solving inequalities and their systems. Maxima has several functions to solve inequalities. Here is a description of some functions.

In order to solve one rational inequality in Maxima, it is advisable to use the function solve_rat_ineq, and to solve the system of linear inequality - fourier_elim. The following approach is proposed to solve systems of rational inequalities. We suggest solving inequalities with the solve_rat_ineq function. Then from the obtained linear inequalities using logical functions or (association) and and (intersection), we build a system of inequalities that we solve with the help of fourier_elim. Let us explain this in the example of solving inequality systems (1).

Let's solve the first system of inequalities (1):

$$
\begin{aligned}
& \text { s 1: solve_rat_ineq }\left(-a^{\wedge} 2+2^{\star} a+3<a^{\wedge} 2\right) \text {; } \\
& {\left[\left[a<-\frac{\sqrt{7}-1}{2}\right],\left[a>\frac{\sqrt{7}+1}{2}\right]\right]}
\end{aligned}
$$

The result is interpreted as follows: $a \in\left(-\infty ;-\frac{\sqrt{7}-1}{2}\right) \cup\left(\frac{\sqrt{7}+1}{2} ;+\infty\right)$. Write it using the function or:

$$
\begin{aligned}
& \text { s1: }(a<-(\operatorname{sqrt}(7)-1) / 2) \text { or }(a>(\operatorname{sqrt}(7)+1) / 2) ; \\
& a<\frac{1-\sqrt{7}}{2} \vee a>\frac{\sqrt{7}+1}{2}
\end{aligned}
$$

Let's solve the second system of inequalities (1):

$$
\begin{aligned}
& \text { s } 2: \text { solve_rat_ineq }\left(-a^{\wedge} 2+2^{*} a+3>0\right) \text {; } \\
& {[[a>-1, a<3]]}
\end{aligned}
$$

The result is interpreted as follows: $a \in(-1 ; 3)$. Write it using the function and:

$$
\begin{aligned}
& s 2:((a>-1) \text { and }(a<3)) \text {; } \\
& a>-1 \wedge a<3
\end{aligned}
$$

Connect s1 and s2 using and and apply the function fourier_elim

fourier_elim (s1 and $s 2,[a])$;

$$
\left[\frac{\sqrt{7}}{2}+\frac{1}{2}<a, a<3\right] \vee\left[-1<a, a<\frac{1}{2}-\frac{\sqrt{7}}{2}\right]
$$

The result obtained is interpreted as follows: $a \in\left(-1 ;-\frac{\sqrt{7}-1}{2}\right) \cup\left(\frac{\sqrt{7}+1}{2} ; 3\right)$, that is, under this condition the roots of the equation $\left|x-a^{2}\right|=-a^{2}+2 a+3$ have the same roots in the sign.

Example 2. How many different solutions does the equation system have

$$
\left\{\begin{array}{c}
x^{2}+y^{2}=8 \\
(y-a x)(y-a \sqrt{2})=0
\end{array}\right.
$$

depending on the parameter value $a[25$, p. 112]? 
Solution. The first equation of the system defines a circle with a center at the origin and a radius to $2 \sqrt{2}$. The second is the set of lines.

$$
\left[\begin{array}{l}
y=a x \\
y=a \sqrt{2}
\end{array}\right.
$$

The first equation of the set determines the family of lines that pass through the origin the center of rotation. The second is a family parallel to $O X$ lines.

Let's turn to graphical visualization (Fig. 3). As you can see, the equation system can have two, three, or four solutions. Obviously, the system has:

1) two solutions provided (Fig. 3, cases 1, 6, 11): $a \in(-\infty ;-2) \cup\{0\} \cup(2 ;+\infty)$;

2) three solutions provided:

- line $\mathrm{y}=\mathrm{a} \sqrt{2}$ is tangent to the circle $\mathrm{x}^{2}+\mathrm{y}^{2}=8$ (this is possible provided $\mathrm{a}=-2$ and $\mathrm{a}=2$ (Fig. 3, cases 2,10));

- lines $y=a x$ and $y=a \sqrt{2}$ and circle $x^{2}+y^{2}=8$ have a common point (this is possible provided $\mathrm{a}=-\sqrt{3}$ and $\mathrm{a}=\sqrt{3}$, (Fig. 3 , cases 4,8 )). In this case, to find the values of the parameter a you need to solve the equation system, excluding from consideration $\mathrm{a}=0$ :

$$
\left\{\begin{array}{c}
x^{2}+y^{2}=8 \\
y=a x \\
y=a \sqrt{2} \\
a \neq 0
\end{array}\right.
$$

In Maxima, this can be done using the function solve, previously from the second equation of the system expressing $x=\frac{y}{a}(\mathrm{x}: \mathrm{y} / \mathrm{a})$

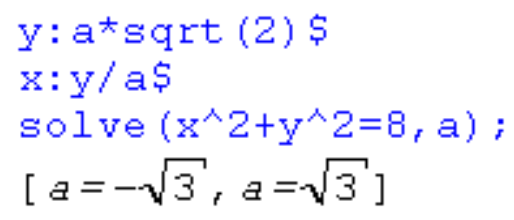

3) four solutions provided (Fig. 3, cases $3,5,7,9) a \in(-2 ;-\sqrt{3}) \cup(-\sqrt{3} ; 0) \cup$ $(0 ; \sqrt{3}) \cup(\sqrt{3} ; 2)$.

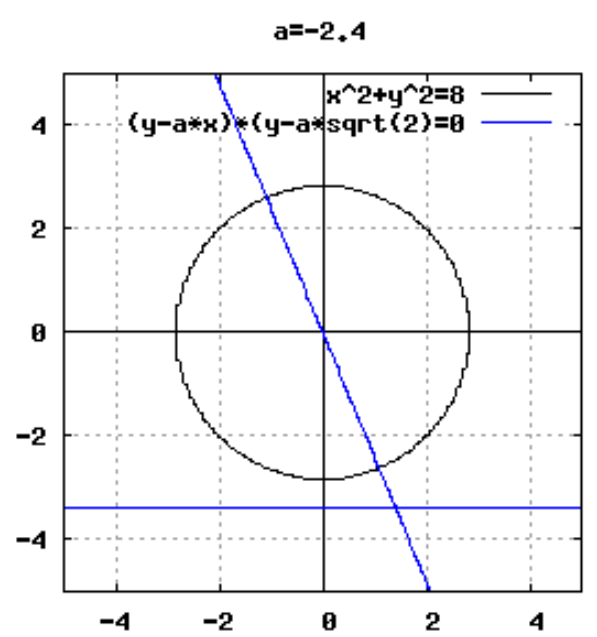

case 1

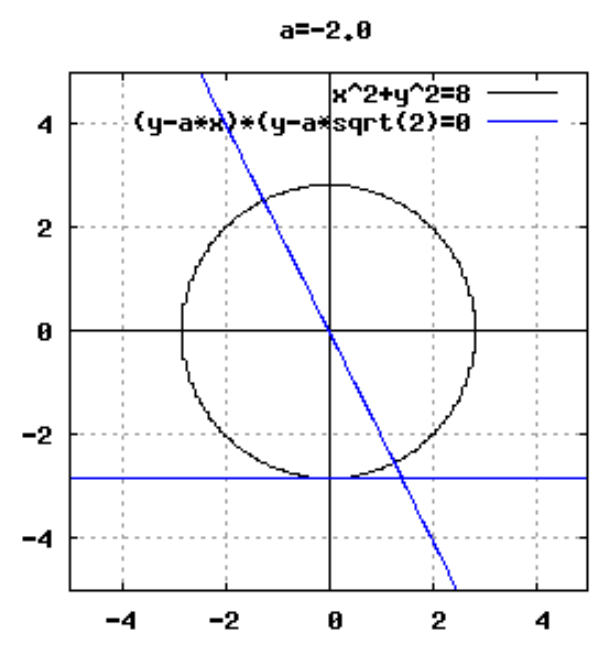

case 2 

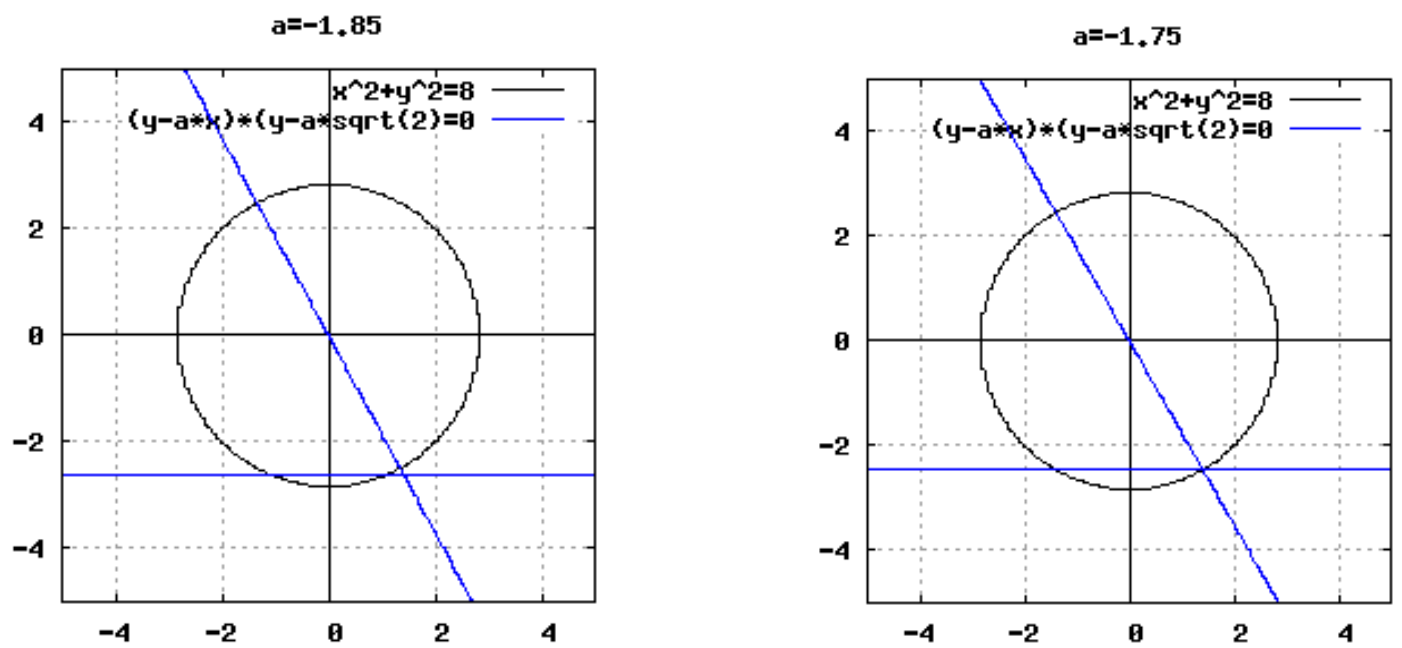

case 3

$a=-0.75$

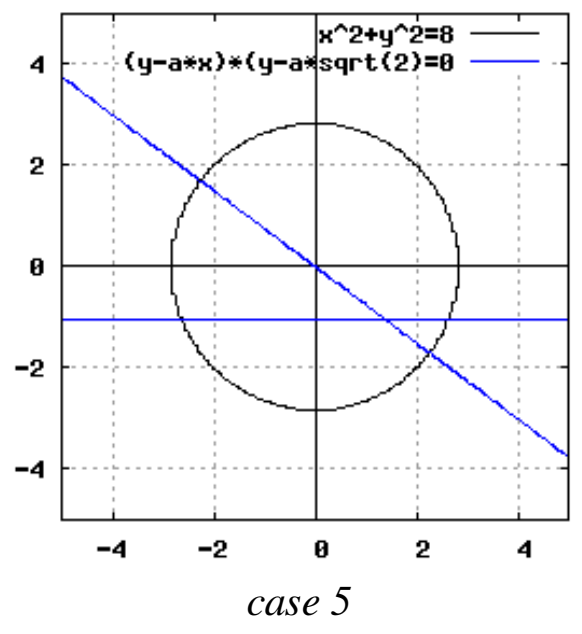

$\mathbf{a}=\mathbf{0 . 9}$

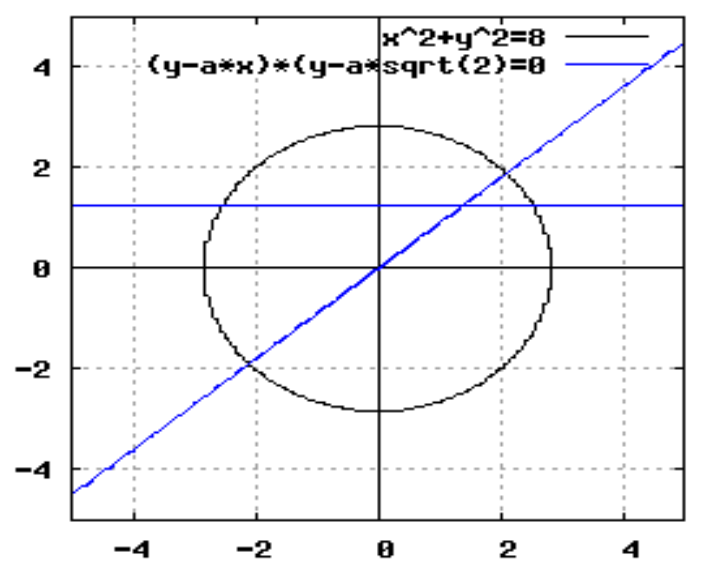

case 4

$\mathrm{a}=\mathbf{0}$
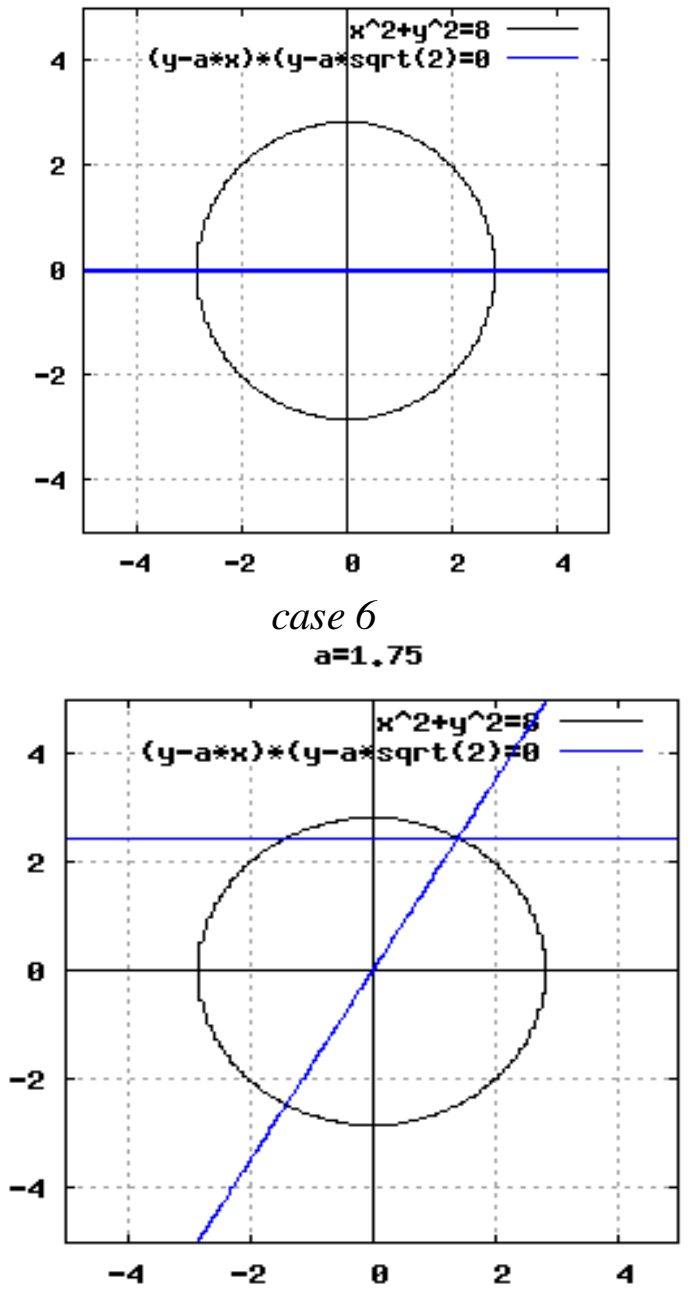

case 7

case 8 

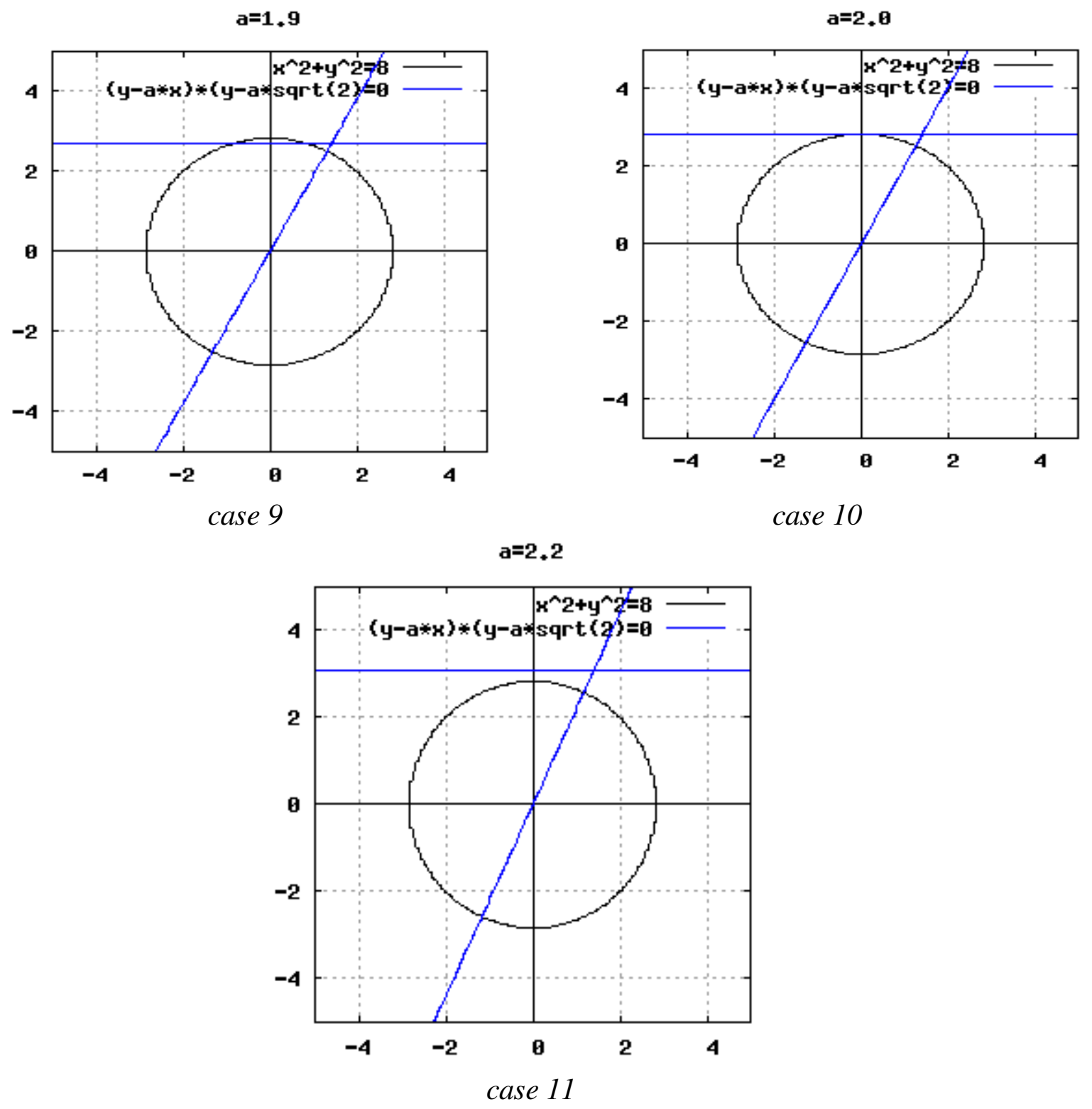

Fig. 3

Example 3. How many solutions does the equation system have

$$
\left\{\begin{array}{c}
|x|+|y|=a \\
x^{2}+y^{2}=1
\end{array}\right.
$$

depending on the parameter value $a$ [25, p. 117]?

Solution. First of all, note that if $a \leq 0$ the system of equations has no solution. The first equation of the system defines a family of homothetic squares with vertices lying on the coordinate axes and with the center of homotathy in p.(0;0), the second - a circle with a center at the origin and a radius equal to 1. Having made a graphic illustration (Fig. 4), we can see that the system of the equation:

1) has no solutions: (Fig. 4, cases 1,5$) a \in(-\infty ; 1) \cup(\sqrt{2} ; \infty)$;

2) has four solutions (Fig. 4, cases 2, 4): square inscribed in a circle $(a=1)$ or square inscribed in a circle $(a=\sqrt{2})$;

3) has eight solutions (Fig. 4 , case 3$): a \in(1 ; \sqrt{2})$. 
$a=0.7$

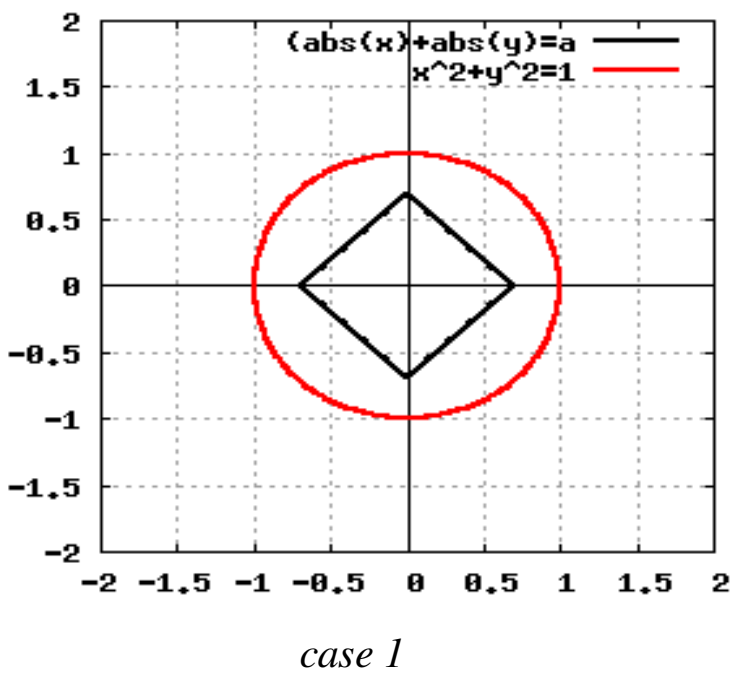

$a=1.25$

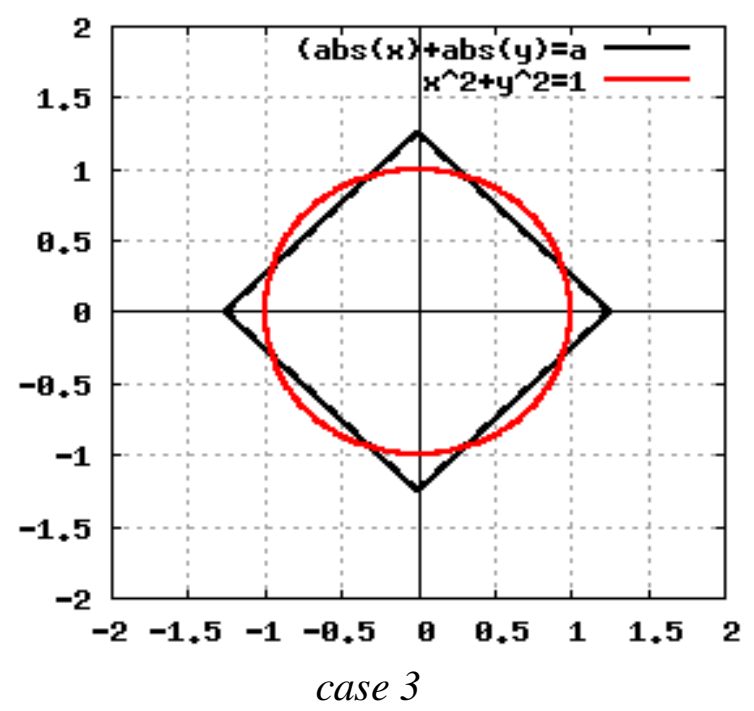

$\mathbf{a}=\mathbf{1 . 0}$

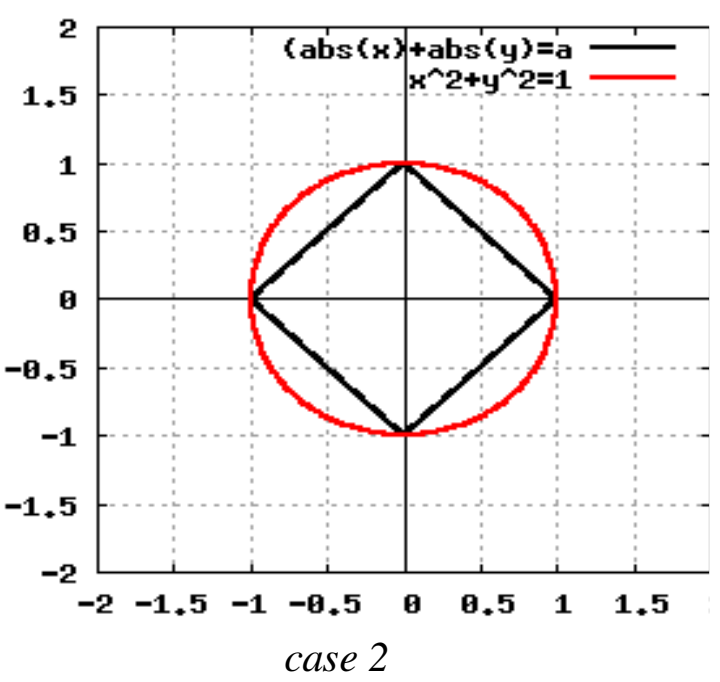

$\mathbf{a}=1.45$

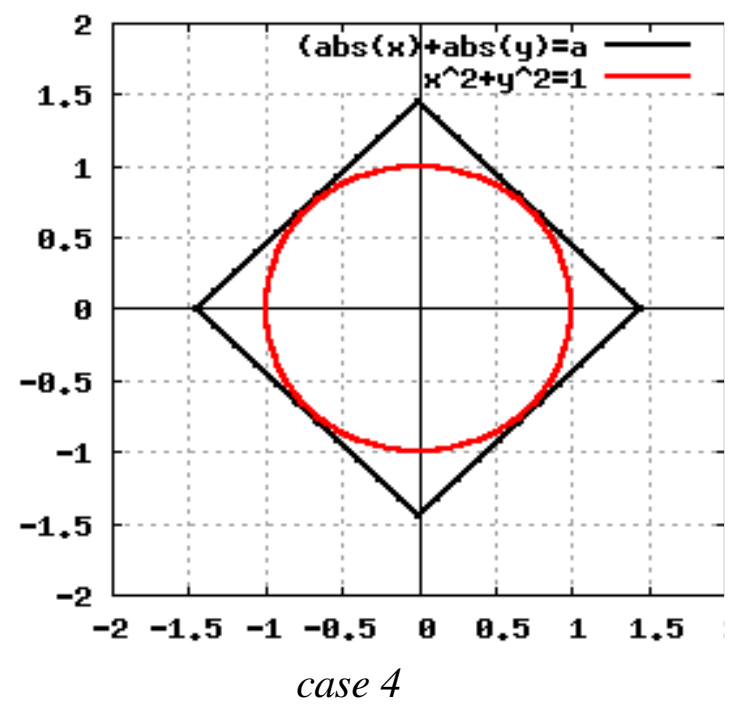

$a=1.55$

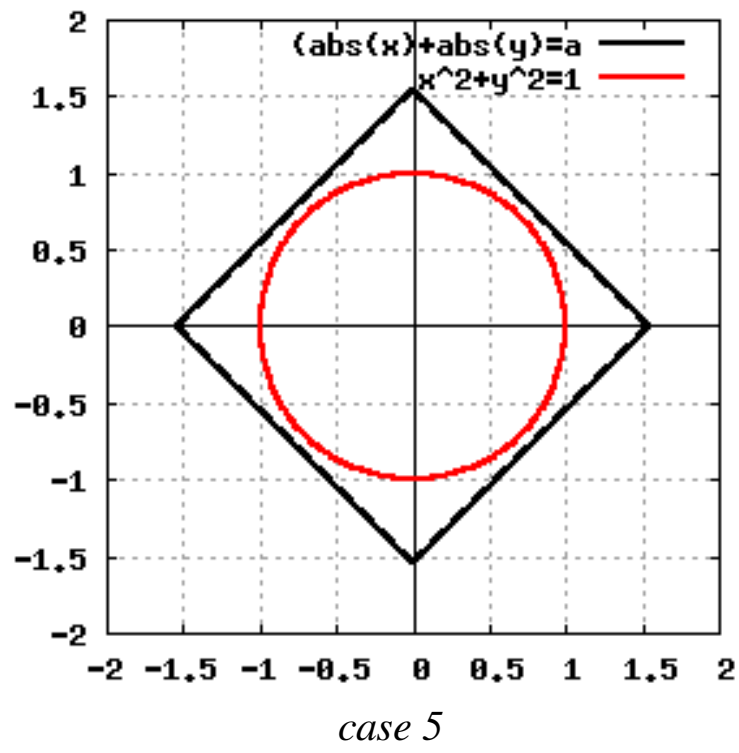

Fig. 4 
Example 4. How many solutions does the system have

depending on the parameter $c[25$, p. 136]?

$$
\left\{\begin{array}{l}
y-x^{2}=c \\
x-y^{2}=c
\end{array}\right.
$$

Solution. Write this system as follows

$$
\left\{\begin{array}{c}
y=x^{2}+c \\
x-\left(x^{2}+c\right)^{2}=c
\end{array}\right.
$$

Obviously, the number of roots of the second equation is equal to the number of roots of the system itself. Therefore, we will solve the second equation of the system with respect to $c$ :

$$
\begin{aligned}
& \text { al: solve }\left(x-\left(x^{\wedge} 2+c\right)^{\wedge} 2=c, c\right) \text {; } \\
& {\left[c=-x^{2}-x-1, c=x-x^{2}\right]}
\end{aligned}
$$

We obtain a set of equations:

$$
\left[\begin{array}{c}
c=-x^{2}-x-1 \\
c=-x^{2}+x
\end{array}\right.
$$

In the coordinate plane $x O c$ build graphs (Fig. 5) $c(x)=-x^{2}-x-1$ and $c(x)=$ $-x^{2}+x$

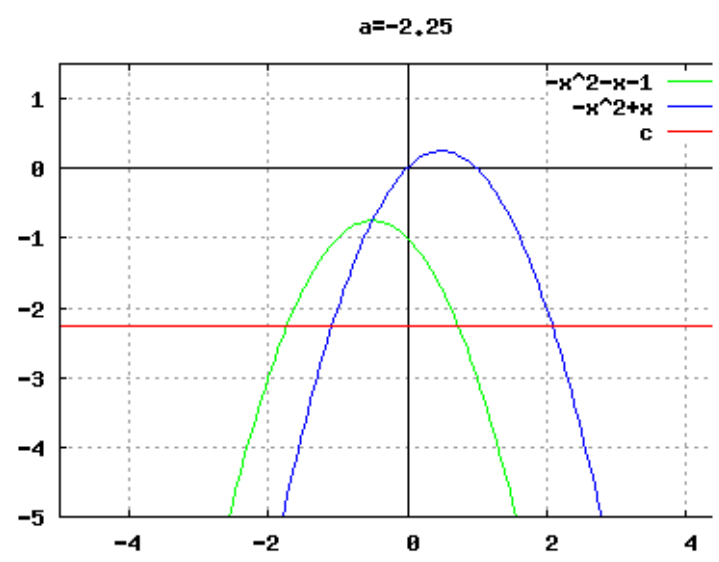

case 1

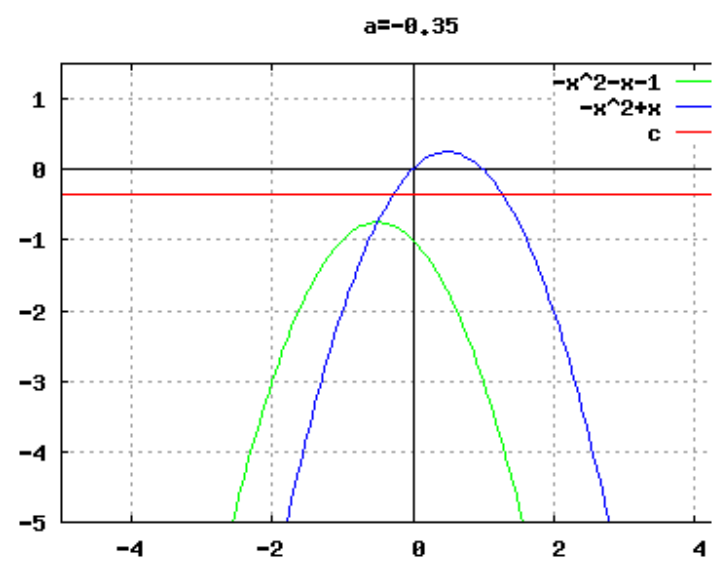

case 3

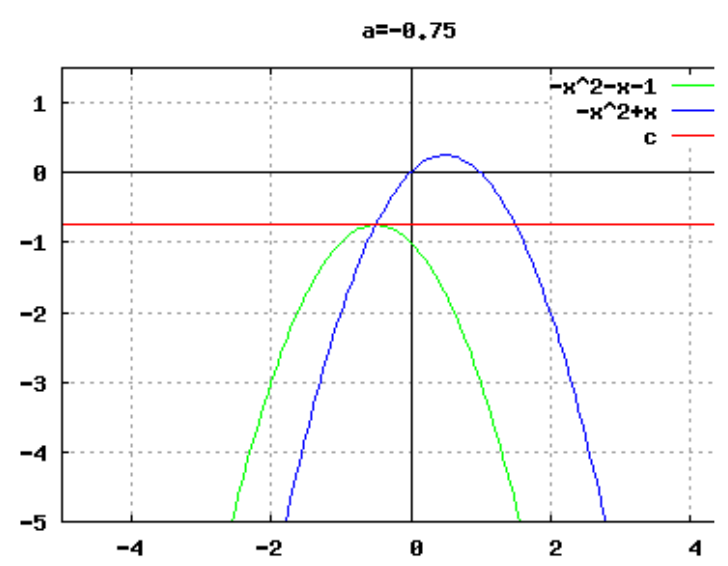

case 2

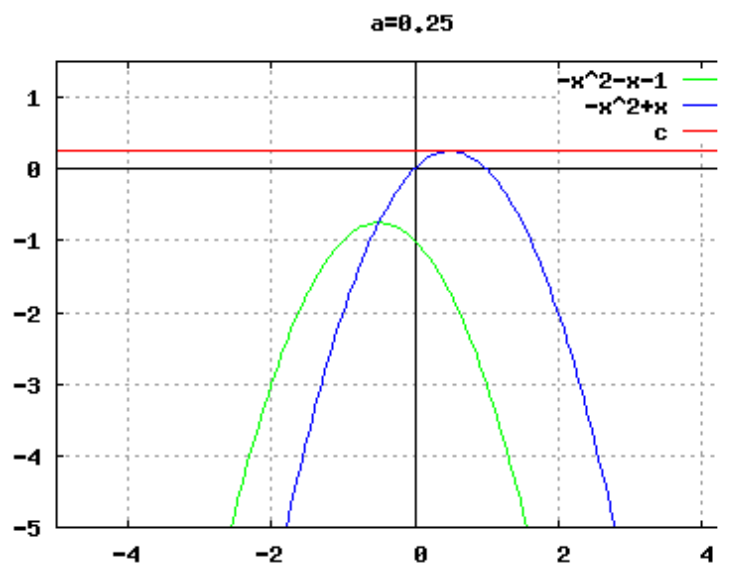

case 4 


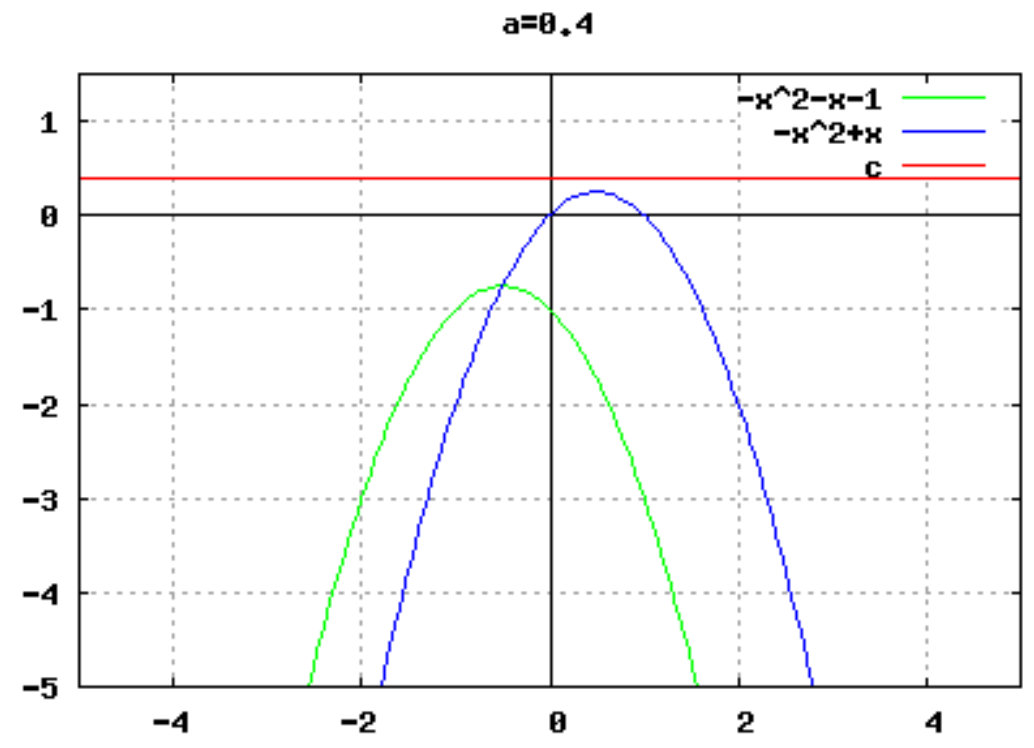

case 3

Fig. 5

Analysis of the graphical visualization of the task shows that in order to answer the question, it is necessary to find the ordinates of the vertices of the parabola and their point of intersection.

The intersection point of the parabola is as follows:

$$
\begin{aligned}
& \text { solve }(e v(c, a 1[1])=e v(c, a 1[2]), x) ; \\
& \text { ev }\left(a 1[1], \frac{s}{5}\right) ; \\
& {\left[x=-\frac{1}{2}\right]} \\
& c=-\frac{3}{4}
\end{aligned}
$$

Parabolic vertex coordinates $c=-x^{2}-x-1$ and $c=-x^{2}+x$ respectively are $c=-\frac{3}{4}$ and $c=\frac{1}{4}$. It should be noted that the intersection point of the parabola coincides with the vertex of the parabola $c=-x^{2}-x-1$.

Now we can write the answer:

1) if $c \in\left(-\infty ;-\frac{3}{4}\right)$, then the system has four solutions (Fig. 5, case 1);

2) if $c \in\left[-\frac{3}{4} ; \frac{1}{4}\right.$ ), then the system has two solutions (Fig. 5, case 2, case 3);

3) if $c=\frac{1}{4}$, then the system has one solution (Fig. 5, case 4);

4) if $c \in\left(\frac{3}{4} ;+\infty\right)$, then the system has no solutions (Fig. 5, case 5).

Example 5. Find all parameter values $a$, in which the system of inequalities

has single solution [25, p. 133].

$$
\left\{\begin{array}{l}
x^{2}+2 x+a \leq 0 \\
x^{2}-4 x-6 a \leq 0
\end{array}\right.
$$

Solution. We write this system as

$$
\left\{\begin{array}{l}
a \leq-x^{2}-2 x \\
a \geq \frac{x^{2}-4 x}{6}
\end{array}\right.
$$


All solutions of the system, i.e. pairs, $(x ; a)$ form an area, which is depicted in Fig. 6. By default, among all the solutions we should select the ones when the system has a single solution. Graphically, this means that straight lines parallel to the axis $O X$ should have one point in common with the outlined area. We draw a sketched area with a function region. As can be seen from Fig. 6, this is possible if:

1) line $a=c(c=$ const $)$ passes through the intersection point of the parabola $a(x)=$

$=\frac{x^{2}-4 x}{6}$ and $a(x)=-x^{2}-2 x$ (Fig. 6, case 1). To find the parameter value $a$ it is necessary to solve a system of equations

$$
\left\{\begin{array}{l}
a=-x^{2}-2 x \\
a=\frac{x^{2}-4 x}{6} .
\end{array}\right.
$$

and choose the smallest of its possible values (as can be seen from the graphic illustration), that is $a=0$ :

$$
\begin{aligned}
& \text { solve }\left(\left[a=-x^{\wedge} 2-2^{\star} x, a=\left(x^{\wedge} 2-4^{*} x\right) / 6\right],[a, x]\right) \text {; } \\
& {\left[\left[a=\frac{48}{49}, x=-\frac{8}{7}\right],[a=0, x=0]\right]}
\end{aligned}
$$

2) line $a=c$ is tangential to the parabola $a(x)=-x^{2}-2 x$, that is, it passes through its top. This is possible provided $a=1$. (Fig. 6, case 2).

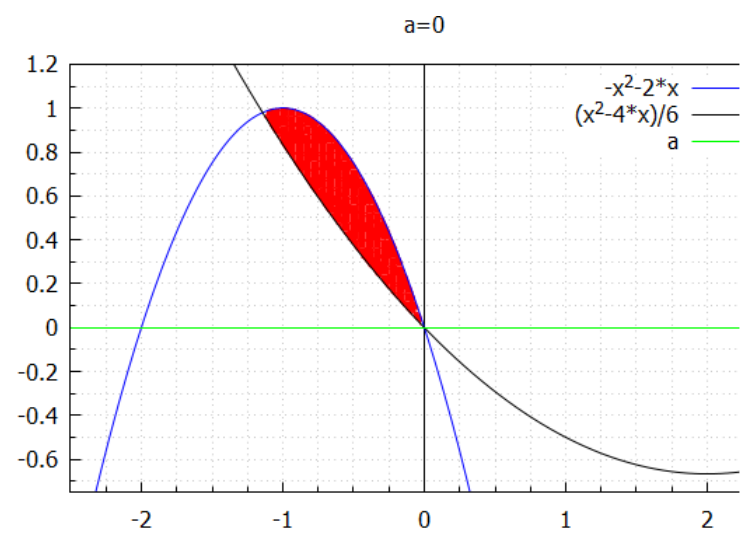

case 1

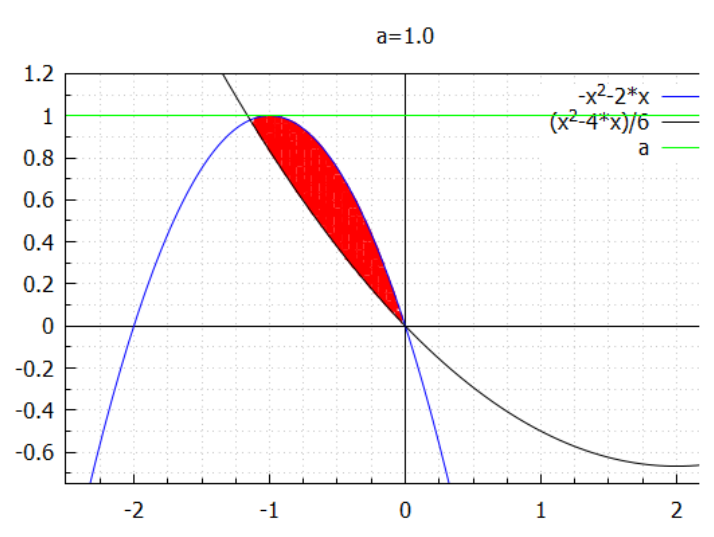

case 2

Fig. 6

The only solution is to have a system of inequalities if $a=0$ або $a=1$.

\section{CONCLUSIONS AND PROSPECTS OF FURTHER RESEARCH}

The results of the study show that one of the mechanisms for the formation of research skills is the task with parameters, for which it is advisable to use ICT, including CAS Maxima. Such an approach in teaching will contribute to the formation of an algorithmic style of thinking, the ability to analyze, systematize, model and predict. The acquired competences will be useful for IT students to properly master courses in professional training, including algorithms and programming, modeling, the basics of artificial intelligence, optimization methods and operations research, etc. 
Solving tasks with parameters requires a certain level of development of logical and abstract thinking, the ability to analyze and generalize. Tasks with parameters require studies of a more general nature than ordinary equations, inequalities and their systems. Solving tasks with parameters helps to improve the ability to think logically, to refine the logical methods of thinking (analysis, synthesis, comparison, concretization, and generalization) required for professional growth, for teachers of informatics in particular.

The use of a research approach in the educational process is effective under the conditions of pedagogically balanced use of CAS, whereby it is possible to focus on training meaningful, creative aspects of educational and cognitive activity and to leave the routine and time-consuming work to the computer.

We chose the Maxima system as a tool for researching tasks with parameters. In our opinion, it is actually the system that is appropriate to use in pedagogical universities for teaching computer modeling to students of physical, mathematical and informatical specialties.

Further research will focus on expanding the range of research tasks with parameters that can be solved using the proposed Maxima system, as well as comparisons with other software products.

\section{REFERENCES (TRANSLATED AND TRANSLITERATED)}

[1]. A.V. Pruss, and V.O. Shvets, "Tasks with Parameters in a School Mathematics Course." Zhytomyr, Ukraine: Ruta Publishing House, 2016. (in Ukrainian)

[2]. O.O. Hrybiuk, and V.L. Yunchyk, "Features of Using the System Geogebra in Teaching Course "Mathematical Foundations of Informatics," Mathematics. Information Technology. Education 1(4), pp.35-49, 2017. (in Ukrainian)

[3]. S. Ursini, and M.Trigueros, "How Do High School Students Interpret Parameters in Algebra?", In M. J. Hoines \& A. B. Fuglestad (Eds.), Proceedings of the 28th Conference of the International Group for the Psychology of Mathematics Education, Vol. 4, pp. 361-368, Bergen University College, 2004. (in English)

[4]. V. Bykov, and M.Shyshkina, "The Conceptual Basis of the University Cloud-based Learning and Research Environment Formation and Development in View of the Open Science Priorities," Information Technologies and Learning Tools, 2018. doi: https://doi.org/10.33407/itlt.v68i6.2609.(in English)

[5]. M. Marienko, Yu. Nosenko, F. Sukhikh, V. Tataurov, and M. Shyshkina, "Personalization of Learning Through Adaptive Technologies in the Context of Sustainable Development of Teachers' Education," E3S Web of Conferences, Vol. 166, 2020. doi: https://doi.org/10.1051/e3sconf/202016610015 (in English)

[6]. S.Abramovich, and A.Ehrlich, "Computer as a Medium for Overcoming Misconceptions in Solving Inequalities," Journal of Computers in Mathematics and Science Teaching, 26(3), pp.181-196, 2007. (in English)

[7]. A. Kumar, and S. Kumareson, "Use of Mathematical Software for Teaching and Learning," Proceedings of 11th International Congress on Math Education (ICME), July, 6-13, Mexico, pp.373-388, 2008. (in English)

[8]. F. Botana, M. Abánades, and J. Escribano. "Using a Free Open Source Software to Teach Mathematics," Computer Applications in Engineering Education, 22 (4), pp. 728-735, 2014, doi.org/10.1002/cae.21565(in English)

[9]. T. V. Pidgorna, "Theoretical and Methodological Bases of Preparation of Future Teachers of Natural and Mathematical Disciplines for Professional Activity in the Conditions of Informatized Educational Process," Doctor's dissertation. National Pedagogical Dragomanov University. Kyiv, Ukraine, 2018. (in Ukrainian)

[10]. M.I. Zhaldak, Yu.V. Goroshko, Ye.F. Vinnichenko, and G.Yu. Tsybko, "Mathematics with a Computer (with GRAN1)," the Teacher's Guide, Third Edition, supplemented. Kyiv, Ukraine: National Dragomanov Pedagogical University, 305 p., 2016. (in Ukrainian)

[11]. N.O. Bugayets, " Development of Educational and Research Skills of Students of Physical and Mathematical Specialties in the Process of Teaching Mathematical Informatics," Ph.D. thesis, National Pedagogical Dragomanov University, Kviv, Ukraine, 2016. (in Ukrainian) 
[12]. K. Fuchs, "Teaching Meaningful Mathematics with the Computer Algebra System Maxima Using the Example of Inequalities," Teaching Mathematics and Computer Science, pp. 53-65, 2013, doi: 10.5485/tmcs.2013.0331(in English)

[13]. N.O. Bugayets, "Modeling of Animation Visuals by Means of the Maxima Program Graphic Environment," Information Technologies and Learning Tools, Vol. 47, №3, pp.67-79, 2015. doi: https://doi.org/10.33407/itlt.v47i3.1244 (in Ukrainian)

[14]. O.O. Hrybiuk, and V.L. Yunchyk, "Using Computer Algebra Systems in the Context of a Blended Learning Model," Mathematics. Information Technology. Education: [Coll. articles], Lesya Ukrainka SNU, Lutsk, pp. 52-71. 2015. (in Ukrainian)

[15]. V.M. Rakuta, "GeoGebra Dynamic Mathematics System as an Innovative Tool for the Study of Mathematics," Information Technologies and Learning Tools, №4 (30). 2012. https://doi.org/10.33407/itlt.v30i4.700. (in Ukrainian)

[16]. B.-S. Ilany, and D. Hassidov, "Solving Equations with Parameters," Creative Education, 5, pp.963968.2014, doi: 10.4236/ce.2014.511110. (in English)

[17]. S. Abramovich, and A. Norton. "Equations with Parameters: a Locus Approach," Journal of Computers in Mathematics and Science Teaching 25(1), pp. 5-28, 2006.

[18]. S. Goncharenko, "Ukrainian Pedagogical Dictionary," S. Golovko and S. Caverin, Eds., Kyiv: Lybid, 1997. (in Ukrainian)

[19]. I.Ya. Lerner, "Didactic Foundations of Teaching Methods," M .: Pedagogy, 1981. (in Russian)

[20]. V.N. Litovchenko, "Formation of Research Skills of Students of Pedagogical Specialties of the University by Means of NIR," Ph.D. dissertation, Minsk, 1990. (in Russian)

[21]. Ye. I. Mashbits, "Psychological Bases of Management of Educational Activity," Kyiv: Higher school, 1987. (in Russian)

[22]. M.I. Zhaldak, "Informatics Is a Fundamental Scientific Discipline. She Must Study the Laws of Nature, Information Processes and Related Technologies (continued)," Computer in School and Family, № 3, pp. 7-11, 2010. (in Ukrainian)

[23]. Ye.F. Vinnichenko, "Development of Creative Abilities of High School Students in the Process of Learning Information Technologies for Solving Mathematical Problems," Ph.D. dissertation, National Pedagogical Dragomanov University. Kyiv, Ukraine, 2006. (in Ukrainian)

[24]. E.V. Mayevsky, and P.V.Yagodovsky, "Computer Mathematics. Higher Mathematics at CAS Maxima: A Tutorial," Moscow: Financial University, 196 p., 2014. (in Russian)

[25]. P.I. Gornstein, V.B. Polonsky, and M.S. Yakir, "Tasks with Parameters," Kyiv: RIA "Text”; MP "OKO", Kiev, Ukraine, 290 p., 1992. (in Russian)

Text of the article was accepted by Editorial Team 15.03.2020

\title{
СИСТЕМА МАХІМА ЯК ЗАСІБ ФОРМУВАННЯ ДОСЛІДНИЦЬКИХ УМІНЬ МАЙБУТНІХ УЧИТЕЛІВ ІНФОРМАТИКИ
}

\author{
Кобильник Тарас Петрович \\ кандидат педагогічних наук, доцент, доцент кафедри інформатики та інформаційних систем \\ Дрогобицький державний педагогічний університет імені Івана Франка, м. Дрогобич, Україна \\ ORCID ID 0000-0002-2703-7570 \\ kobylnyktaras@gmail.com
}

Когут Уляна Петрівна

кандидат педагогічних наук, доцент, доцент кафедри інформатики та інформаційних систем Дрогобицький державний педагогічний університет імені Івана Франка, м. Дрогобич, Україна ORCID ID 0000-0002-2861-2274

ulyana300l@gmail.com

\section{Винницька Наталія Володимирівна}

кандидат педагогічних наук, доцент кафедри математики, інформатики та методики їх викладання у початковій школі Дрогобицький державний педагогічний університет імені Івана Франка, м. Дрогобич, Україна ORCID ID 0000-0003-2784-3465

Natalya.86@ukr.net 


\begin{abstract}
Анотація. У статті розглянуто проблему, що стосується формування дослідницьких умінь студентів педагогічних університетів. Значна увага приділяється формуванню творчого мислення студентів у процесі розв'язування задач з параметрами. Необхідність розв’ язувати задачі з параметрами (у межах побудованої математичної моделі) обумовлена великою кількістю прикладних задач, зокрема економічних, фізичних, хімічних, біологічних, технічних, медичних тощо. Задачі $з$ параметрами вимагають досліджень більш загального характеру, ніж звичайні рівняння, нерівності та їх системи. У статті розв’язування задач 3 параметрами супроводжується графічною візуалізацією 3 подальшим використанням аналітичного методу. Для графічної візуалізації (анімації) використано СКМ Махіта. Вибір задач 3 параметрами обумовлений тим, що в процесі їх розв’язування розвивається математичне, логічне мислення, уміння аналізувати, порівнювати, узагальнювати, формуються навички дослідницької діяльності. Все це має призвести до пошуку i впровадження нових педагогічних форм i технологій в освіті. Головний компонент методичної системи - комп'ютерна орієнтація, а саме використання системи комп'ютерної математики. Використовуючи системи комп'ютерної математики, студент може: удосконалювати техніку програмування та уміння зосереджувати увагу на аналізі методів, занурюватись в особливості таких понять, як обумовленість задачі, стабільність методу, оцінка результатів обчислень. У роботі для дослідження задач 3 параметрами ми використовували засоби анімації СКМ Maxima 3 графічною оболонкою wхМахіта. Вибір системи Махіта пояснюється такими причинами: вільно поширювана система, поширюється за ліцензією GNU/GPL; $є$ реалізації під різні операційні системи, зокрема Windows, Linux, MacOS; наявність інтуїтивно-зрозумілого інтерфейсу; простота та надійність у роботі. Результати дослідження показують, що ефективність підготовки сучасних фахівців, розвиток їх професійного потенціалу реалізується в залученні студентів до дослідницької діяльності протягом усього навчання.
\end{abstract}

Ключові слова: задачі 3 параметрами; дослідницькі уміння; системи комп'ютерної математики; Maxima.

\title{
СИСТЕМА МАХІМА КАК СРЕДСТВО ФОРМИРОВАНИЯ ИССЛЕДОВАТЕЛЬСКИХ УМЕНИЙ БУДУЩИХ УЧИТЕЛЕЙ ИНФОРМАТИКИ
}

\author{
Кобыльник Тарас Петрович \\ кандидат педагогических наук, доцент, доцент кафедры информатики и информационных систем \\ Дрогобычский государственный педагогический университет имени Ивана Франко \\ г. Дрогобыч, Украина \\ ORCID ID 0000-0002-2703-7570 \\ kobylnyktaras@gmail.com
}

Когут Ульяна Петровна

кандидат педагогических наук, доцент, доцент кафедры информатики и информационных систем Дрогобычский государственный педагогический университет имени Ивана Франко, г. Дрогобыч, Украина

ORCID ID 0000-0002-2861-2274

ulyana300l@gmail.com

\author{
Винницкая Наталья Владимировна \\ кандидат педагогических наук, \\ доцент кафедры математики, информатики и методики их преподавания в начальной школе \\ Дрогобычский государственный педагогический университет имени Ивана Франко \\ г. Дрогобыч, Украина \\ ORCID ID 0000-0003-2784-3465 \\ Natalya.86@ukr.net
}

Аннотация. В статье рассмотрена проблема, касающаяся формирования исследовательских умений студентов педагогических университетов. Значительное внимание уделяется формированию творческого мышления студентов в процессе решения задач с параметрами. 
Необходимость решения задач с параметрами (в рамках построенной математической модели) обусловлена большим количеством прикладных задач, в частности экономических, физических, химических, биологических, технических, медицинских и др. Задачи с параметрами требуют исследований более общего характера, чем обычные уравнения, неравенства и их системы. В статье решения задач с параметрами сопровождаются графической визуализацией с последующим использованием аналитического метода. Для графической визуализации (анимации) использовано СКМ Махіта. Выбор задач с параметрами обусловлен тем, что в процессе их решения развивается математическое, логическое мышление, умение анализировать, сравнивать, обобщать, формируются навыки исследовательской деятельности. Все это должно привести к поиску и внедрению новых педагогических форм и технологий в образовании. Главный компонент методической системы - компьютерная ориентация, а именно использование системы компьютерной математики. Используя системы компьютерной математики, студент может: совершенствовать технику программирования и умение концентрировать внимание на анализе методов, погружаться в особенности таких понятий, как обусловленность задачи, стабильность метода, оценка результатов вычислений. В работе для исследования задач с параметрами мы использовали средства анимации СКМ Махіma с графической оболочкой wхMaхima. Выбор системы Maхima объясняется следующими причинами: свободно распространяемая система, распространяется по лицензии GNU / GPL; есть реализации под различные операционные системы, в том числе Windows, Linux, MacOS; наличие интуитивно-понятного интерфейса; простота и надежность в работе. Результаты исследования показывают, что эффективность подготовки современных специалистов, развития их профессионального потенциала реализуется в привлечении студентов к исследовательской деятельности на протяжении всего обучения.

Ключевые слова: задачи с параметрами; исследовательские умения; системы компьютерной математики; Maxima.

\section{(cc) EY-NC-SA}

This work is licensed under Creative Commons Attribution-NonCommercial-ShareAlike 4.0 International License. 